\title{
Climate change impacts in the design of drainage systems: case study of Portugal
}

Article

Accepted Version

Modesto Gonzalez Pereira, M. G., Sanches Fernandes, L. F., Barros Macário, E. M., Gaspar, S. M. and Pinto, J. G. (2015)

Climate change impacts in the design of drainage systems:

case study of Portugal. Journal of Irrigation and Drainage

Engineering, 141 (2). 05014009. ISSN 0733-9437 doi: https://doi.org/10.1061/(ASCE)IR.1943-4774.0000788 Available at https://centaur.reading.ac.uk/37936/

It is advisable to refer to the publisher's version if you intend to cite from the work. See Guidance on citing.

Published version at: http://dx.doi.org/10.1061/(ASCE)IR. 1943-4774.0000788

To link to this article DOI: http://dx.doi.org/10.1061/(ASCE)IR.1943-4774.0000788

Publisher: American Society of Civil Engineers

All outputs in CentAUR are protected by Intellectual Property Rights law, including copyright law. Copyright and IPR is retained by the creators or other copyright holders. Terms and conditions for use of this material are defined in the End User Agreement.

\section{www.reading.ac.uk/centaur}

\section{CentAUR}


Central Archive at the University of Reading

Reading's research outputs online 


\section{Climate change impacts in the design of drainage systems -}

4 Mário Jorge Modesto Gonzalez Pereira ${ }^{1}$; Luís Filipe Sanches Fernandes ${ }^{2}$;

5 Eduarda Maria Barros Macário ${ }^{3}$; Sónia Morgado Gaspar ; Joaquim Ginete

6 Pinto $^{5}$

7

8

9

Final word version from:

Pereira MG, Sanches Fernandes LF, Macário E, Gaspar S, Pinto JG (2015) Impact of Projected Climate Change in the Design of Urban Stormwater Drainage Systems - A

Case Study for Portugal. J. Irrig. Drain. Eng., 141, 05014009.

doi:10.1061/15(ASCE)IR.1943-4774.0000788

\footnotetext{
${ }^{1}$ Assistant Professor, Centre for the Research and Technology of Agro-Environmental and Biological Sciences, CITAB, University of Trás-os-Montes and Alto Douro, UTAD, Quinta de Prados, 5000-801 Vila Real, Portugal; and IDL, Faculdade de Ciências da Universidade de Lisboa, Campo Grande, Edifício C8, Piso 3, 1749-016 Lisboa, Portugal (corresponding author). E-mail: gpereira@utad.pt

${ }^{2}$ Assistant Professor, Centre for the Research and Technology of Agro-Environmental and Biological Sciences, CITAB, University of Trás-os-Montes and Alto Douro, UTAD, Quinta de Prados, 5000-801 Vila Real, Portugal; and Department of Engineering, University of Trás-os-Montes and Alto Douro, UTAD, Quinta de Prados, 5000-801 Vila Real, Portugal. E-mail: Ifilipe@utad.pt

${ }^{3}$ M.Sc. Graduate of Civil Engineering, Department of Engineering, University of Trás-os-Montes and Alto Douro, UTAD, Quinta de Prados, 5000-801 Vila Real, Portugal.E-mail: edu.mbmacario@gmail.com

${ }^{4}$ M.Sc. Graduate of Civil Engineering, Department of Engineering, University of Trás-os-Montes and Alto Douro, UTAD, Quinta de Prados, 5000-801 Vila Real, Portugal. E-mail: snmorgado09@gmail.com

${ }^{5}$ Associate Professor in Regional Climate and Synoptic Meteorology, Department of Meteorology, University of Reading, Whiteknights, PO Box 217, Reading, Berkshire, RG6 6AH, United Kingdom; and Institute for Geophysics and Meteorology, University of Cologne, Pohligstr. 3, D-50969 Köln, Germany. E-mail: j.g.pinto@reading.ac.uk; and, jpinto@meteo.uni-koeln.de
} 


\section{Abstract}

17 This study aims to assess the necessity of updating the Intensity-Duration-Frequency 18 (IDF) curves used in Portugal to design building storm-water drainage systems. A comparative analysis of the design was performed for the three pre-defined rainfall regions in Portugal using the $I D F$ curves currently in use and estimated for future decades. Data for recent and future climate conditions simulated by a global/regional climate model chain (ECHAM5/MPI-OM1/COSMO-CLM) are used to estimate possible changes of rainfall extremes and its implications for the drainage systems. The methodology includes the disaggregation of precipitation up to sub-hourly scales, the robust development of IDF curves and the correction of model bias. Obtained results indicate that projected changes are largest for the plains in Southern Portugal (5 - 33\%) than for mountainous regions $(3-9 \%)$ and that these trends are consistent with projected changes in the long term $95^{\text {th }}$-percentile of the daily precipitation throughout the $21^{\text {st }}$ century. We conclude for the need to review the current precipitation regime classification and change the new drainage systems towards larger dimensions to mitigate the projected changes in extreme precipitation.

ASCE Subject Headings: Climate change, Hydraulic design, Drainage systems, Precipitation, Portugal Author keywords: IDF curves; Climate change; Drainage systems design; Extreme precipitation. 
The recent IPCC Special Report on Managing the Risks of Extreme Events and Disasters to Advance Climate Change Adaptation (IPCC 2012) have recently provided evidence that the intensity of extreme precipitation may increase even in areas where total precipitation decreases (Diodato et al. 2011; IPCC 2012). This implies shorter return periods for extreme rainfall. In particular, the changes in the water cycle are likely change the frequency and intensity of floods and droughts for many parts of the world (IPCC 2012); hence, the knowledge of the regime of heavy precipitation in regional terms both under recent and future climate conditions is critical (Beijo et al. 2005; IPCC 2012).

From the engineering point of view, empirical approaches are used to link extremes of precipitation with physical structures. The Intensity-Duration-Frequency (IDF) curves represent key information for the design of urban and building storm-water drainage systems, as they provide maximum precipitation intensity related to a given length and a given return period (Brandão et al. 2001). The IDF curves are mathematically described by the power law behaviour dependence of the precipitation intensity $(I)$ of the duration $(t)$

$$
I=a \times t^{b}
$$

where $a$ and $b$ are the IDF parameters. In Portugal, the designers of building stormwater drainage systems work according to the Portuguese law (DR 1995), which stipulates the IDF curves developed by Matos and Silva (1986). However, long-term trends in rainfall intensities and the projected climate change in terms of the water cycle fosters the assessment of the impact of extreme precipitation in the current and future design of building storm-water drainage systems and the possible update of IDF curves 
(e.g. Fowler and Kilsby 2003 and Vasiljevic et al. 2012). Recently, the impact of climate change on IDF curves have been assessed in several studies performed for the U.S. and Canada (Mailhot et al. 2007; Peck et al. 2012; Zhu et al. 2012; Das et al. 2013; Zhu 2013; Zhu et al. 2013). However, these studies did not assess the possible consequences of such changes to the design of building storm-water drainage systems as the one conducted in northern Europe, for the sewer system of Fredrikstad, Norway by Nie et al. (2009).

Global circulation models (GCM) and regional climate models (RCM) are important tools to study the impact of climate change on meteorological, chemical, hydrological and hydraulic processes. Given pre-defined scenarios of the world development, these models provide projections of different meteorological variables for possible future conditions of the climate system (Meehl et al. 2007; Taylor et al. 2012). The GCMs used for these climate projections have typically resolutions of $100-300 \mathrm{~km}$, which is typically too low for direct use of model output in regional studies. Downscaling techniques, using RCMs, statistical downscaling or a combination of both have been used to obtain results at a finer spatial and temporal time scale (e.g. Maraun et al. 2010). Furthermore, model biases towards the real climate conditions must be adequately assessed, interpreted and corrected before applications can be performed.

In the specific case of urban building drainage systems, the design requires knowledge of rainfall depth intensity values over short periods of time (between minutes to hours). On this assumption, it is necessary to use appropriate methodology capable of performing the disaggregation of daily precipitation depth in sub-daily and sub-hourly precipitation (e.g., Pui et al. 2012). A possible approach is the method of the fragments, introduced by Svanidze in the 1960s (Svanidze 1964, Svanidze 1980), as it is a commonly used method in the precipitation disaggregation (Sharif and Burn, 2007; 
87 Arganis-Juárez et al. 2008) used to obtain the disaggregation coefficients presented in Brandão et al. (2001), which is an official publication of the national Directorate of Services of Water Resources with the results of the analysis of extreme precipitation in Continental Portugal.

Several studies have assessed the impact of climate change on the design of drainage systems, using model simulations/climate scenarios, with converging results in different parts of the world towards increased precipitation intensity and the potential underdesigning of drainage systems (e.g. Nie et al 2009; Rosenberg et al. 2010; He et al. 2011; Rosenzweig et al. 2007). Some of these studies have provided evidence that the design of building storm-water drainage systems may be inadequate or at least under designed for future climate conditions.

The purpose of this study is the assessment of possible changes in the IDF curves and consequent designing of building storm-water drainage systems as a result of changes in the distribution of extreme values of precipitation intensity due to the projected climate change for Continental Portugal. Section 2 deals with description of the data and the methodology used in this study. Results are presented and discussed in section 3. Finally, section 4 is devoted to the conclusions.

\section{Material and Methods}

\section{Database / Data analysis}

In this work, the characterization of intense precipitation was substantiated with three distinct databases. The first database consist of hourly precipitation time series obtained from the database of the Sistema Nacional de Informação e Recursos Hídricos [National System of Water Information and Resources] (SNIRH) for previously 
111 selected weather stations, with the purpose of being representative of the three rainfall 112 areas defined in Matos and Silva (1986), (Fig. 1) and present in the Portuguese 113 Regulation-decree n. ${ }^{\circ}$ 23/95 of August 23 (DR 1995). The selection criteria were based 114 on longevity and quality the historical series of hourly precipitation values (Table 1). 115 Time series cover between 8.2 (Castelo Melhor) and 12 (Covilhã) consecutive years, 116 which corresponds to 72000 and 93000 records, and have less than 5\% of missing 117 values, excepting for stations located in mountainous rainfall region C (Covilhã and 118 Pega) but even so, with the $2^{\text {nd }}$ and $3^{\text {rd }}$ largest number of observed values (92 860 and 84430 records).

With the aim to characterize the spatial distribution of extreme daily precipitation over Continental Portugal, a second database of observed daily rainfall used in this study: The most recent 8.0 version of the E-OBS gridded dataset (0.25 degree regular lat-lon grid), released in April 2013 by ECA\&D (http://www.ecad.eu) project (Haylock et al. 2008).

Finally, the third database consists of precipitation data simulated by the COSMO-CLM [COnsortium for Small-scale MOdelling and Climate Limited-area Modelling and climate conditions, particularly temperature and precipitation, in different regions of 
changes of precipitation over Europe (e.g., Haslinger et al. 2012; Kotlarski et al. 2012) and specifically in Portugal (Costa et al. 2012).

Precipitation indices suggested by the joint project Commission for

Technical Commission for Oceanography and Marine Meteorology Expert Team on

Climate Change Detection and Indices (Frich et al. 2002; Karl et al. 1999; Peterson 2005) are used to study climate change scenarios for precipitation extremes in Portugal (cf. also Costa et al. 2012).

\section{Aggregation and disaggregation of precipitation}

The precipitation datasets described in the previous section are not available on time scales adequate for this study. Consequently, it was necessary to use methods of aggregation and disaggregation of precipitation, in order to have data of maximum precipitation for the duration of $5 \mathrm{~min}, 10 \mathrm{~min}, 15 \mathrm{~min}, 30 \mathrm{~min}, 1 \mathrm{~h}, 2 \mathrm{~h}, 6 \mathrm{~h}, 12 \mathrm{~h}, 24 \mathrm{~h}$ and $48 \mathrm{~h}$. The aggregation process consisted on the use of precipitation depth values obtained for smaller sampling durations to calculate precipitation depth values for higher durations. For example, having hourly precipitation depth, it is rather easy to obtain precipitation depth for 2, 6, 12, 24 and 48 h, simply by summing hourly values that integrate the desired duration. This procedure was adopted for both databases (observed and simulated), for higher durations than the sample ones. The disaggregation of COSMO-CLM daily data to sub-daily data, namely, 1, 2, 6 and $12 \mathrm{~h}$, was performed using the method of fragments or coefficients of disaggregation of the maximum precipitation values. Fragments $\left(w_{i}\right)$ are the fraction of daily precipitation that occurred at a given hour of the day $\left(h_{i}\right)$, 


$$
w_{i}=\frac{h_{i}}{\sum_{i=1}^{24} h_{i}}
$$

161 Consequently, the sum of the coefficients $\left(w_{i}\right)$ for the 24 hours of the day is equal to the unit. Then, to estimate the precipitation depth in each hour of the day $\left(h_{i}^{\prime}\right)$, the corresponding fragment $\left(w_{i}\right)$ is multiplied by the daily precipitation depth $(d)$,

$$
h_{i}^{\prime}=w_{i} \times d
$$

This disaggregation procedure assures that the hourly precipitation estimation $\left(h_{i}^{\prime}\right)$ does not change the total daily precipitation. The disaggregation fragments for 1, 2, 6 and 12 hours were estimated from the hourly observed data by using the Equation (2). Fragments for each duration were computed and sorted in descending order, revealing that the arithmetic averages computed for 50, 100 and 200 highest values were very similar, and were adopted as the values of the coefficients of disaggregation, $w_{i}$. This disaggregation procedure assures that the adopted fragments allow an adequate estimation of the maximum precipitation depth for each duration while retaining consistency with the observed data. The adopted coefficients of disaggregation $w_{i}$ were then applied to daily simulated data by the COSMO-CLM model using Equation (3) to estimate maximum precipitation depth for 1, 2, 6 and 12 hours for each cell of the model grid. This procedure was applied for to the recent and the future periods. The inexistence of observed precipitation data for sub-hourly sampling time compel the disaggregation precipitation process for these temporal scales to rely on the fragments obtained from the relationship between hourly and sub-hourly precipitation proposed for Portugal by Brandão et al. (2001). These disaggregation coefficients are in good agreement with those proposed in the Guide to Hydrological Practices of the World Institute. 


\section{Intensity-Duration-Frequency Curves}

186

187

188

The development of IDF curves that consider future climate conditions is critical for the adequate design of building storm-water drainage systems, as it would allow mitigating a possible change in the frequency and intensity of floods, and thus reducing the damage associated with them. The methodology followed to develop the IDF curves is equivalent to the estimation of the $a$ and $b$ parameters (Equation (1)), which includes the: (i) computation of maximum precipitation intensity time series for each of ten durations (5, 10, 15 and 30 min and 1, 2, 6, 12, 24 and 48 h); (ii) fitting of the Gumbel distribution function to those time series, which mean estimate the location $(\mu)$ and scale $(\sigma)$ parameters in each case (cf. Coles 2001); (iii) estimation of precipitation intensity for each duration and eight different return periods (2, 5, 10, 20, 50, 100, 500 and 1000 years) using Gumbel inverse distribution function; (iv) representation of the precipitation intensity $(\mathrm{mm} / \mathrm{h})$ as a function of precipitation duration $(\mathrm{min})$ in a log-log plot to estimate the slope and intercept regression parameters. This last procedure corresponds to linearization of the Intensity-Duration-Frequency curves (Equation (1)),

$$
\log (I)=\log (a)+b \times \log (t)
$$

which led to the estimation of the ( $a$ and $b$ ) IDF parameters with a statistical significance level of $5 \%$. The quality of the linear regression fit is also assessed by the coefficient of determination $\left(R^{2}\right)$, the F-statistic ( $p$ - value) and the error variance.

The adopted methodology is similar to that described in Brandão et al. (2001). The major differences reside, on the one hand, on the way of adjusting the Gumbel law to 
207 the data (likelihood estimation, using evfit function of MATLAB) and assessing the 208 quality of the fitting, made in this case with the Quantile-Quantile plots and 209 Kolmogorov-Smirnov test (KStest) and the use of robust regression method (RR) to 210 estimate the IDF parameters $a$ and $b$. Major difference of RR in relation to the ordinary 211 least square method (OLS) used in Brandão et al. (2001) lies in the attribution of weights to the observed points, as higher as the corresponding regression residual. A deeper description of the RR method as well as the comparison with OLS may be found in Holland et al. (1977), Huber (1981) and Street et al. (1988).

Many different methods can be used to derive IDF curves, from the usual univariate empirical analysis of the intensity of rainfalls at fixed time intervals, to bivariate frequency analysis using the copula method (Ariff et al. 2012), partial duration series (Ben-Zvi 2009; Kingumbi and Mailhot 2010), multifractal approaches (Garcia-Marin et al. 2013; Veneziano et al. 2013), ensemble empirical mode decomposition and scaling properties (Bougadis and Adamowski 2006; Kuo et al. 2013). Several studies comparing methodologies have been conducted but generally all methods seem to be able to produce accurate IDF estimates (Mohymont et al. 2004; Veneziano et al. 2007; Dame et al. 2008). The type I extreme value, (EVI or Gumbel) distribution has been used successfully in many recent rainfall intensity studies in Europe (Llasat 2001; Bara et al. 2010; Olsson et al. 2012), Asia (Ariff et al. 2012; Ben-Zvi 2009; Ahammed and Hewa 2012), Africa (Kuo et al. 2013; Mohymont et al. 2004) and America (Lumbroso et al 2011; Pizarro et al. 2012). EVI is currently the recommended distribution function for use in Canada and the best choice for the estimation of IDF curves under changing climate conditions (Das et al. 2013). Other distribution functions such as the general extreme value type II (EVII or Fréchet) have also been used, e.g. to estimate the IDF curves using short-record satellite data in Ghana (Endreny and Imbeah 2009). 
232 The estimation of the IDF curves was performed for precipitation simulated by the

233 ECHAM5/MPI-OM1 / COSMO-CLM model chain for the grid cells including the

234 location of the six weather stations (cf. Table 1). With this aim, time series for 30 years

235 period 1971 - 2000 for the C20 scenario, corresponding to the recent past weather

236 conditions, and for two future climate scenarios SRES A1B and B1, regarding the

237 periods $2011-2040,2041-2070$ and 2071-2100, were considered. In general,

238 climate models are not capable of accurately reproduce the observed precipitation.

239 Several methods can be used to correct this bias, ranging from the more traditional

240 methods to the Delta Change approach, in order to include projected future changes in

241 some key precipitation statistics (Olsson et al. 2012; Pereira et al. 2013). The procedure

242 adopted here to correct the model bias is conditioned by just knowing the final values of

243 the IDF parameters proposed in Matos and Silva (1986) and consisted of matching the

244 values of the parameters obtained by the robust regression method for C20 ( $a_{C 20}$ and

$\left.245 b_{C 20}\right)$ with the values ( $a_{M S}$ and $b_{M S}$ ) proposed by Matos and Silva (1986) which are the

246 IDF parameters adopted by the Portuguese law (DR 1995). The correction factor of

247 parameter $a(\Delta a)$ results from the difference between the logarithm of parameter $a_{C 20}$

248 associated to scenario C20 and the logarithm of parameter $a_{M S}$ from Matos and Silva 249 (1986),

250

251

$$
\Delta a=\log _{10} a_{C 20}-\log _{10} a_{M S}
$$

252 In turn, the corrective factor of parameter $b(\Delta b)$ results from the ratio between

253 parameter $b_{C 20}$ associated to scenario C20 and parameter $b_{M S}$ resulting from Matos and 254 Silva’s (1986) study,

$$
\Delta b=\frac{b_{C 20}}{b_{M S}}
$$


256 Afterwards, these same correction factors were applied to parameters $a_{A 1 B}$ and $b_{A 1 B}$

257 obtained for scenario A1B, proceeding as follows:

258

259

$$
a_{A 1 B \text { corr }}=10^{\left(\log _{10} a_{A 1 B}-\Delta a\right)}
$$

260

and

$$
b_{A 1 B \text { corr }}=\frac{b_{A 1 B}}{\Delta b}
$$

261

262 which allowed obtaining corrected versions of parameters $a$ and $b$. The same procedure

263 was applied to intermediate results obtained for scenario B1.

264 The two-sample Kolmogorov-Smirnov test is used to compare the distributions of the precipitation depth intensity simulated for future $\left(I_{\text {future }}\right)$ and recent climate conditions $\left(I_{\text {past }}\right)$. The null hypothesis is that $I_{\text {future }}$ and $I_{\text {past }}$ are from the same continuous distribution, while the alternative hypothesis is that they belong to different continuous distributions. In both cases, the IDF curves $\left(I=a \times t^{b}\right)$ are used to generate $I$ values for different duration times, by resorting to parameters estimated for future periods/scenarios after correcting climate model bias and proposed by Matos and Silva (1986), respectively.

\section{Design of the urban building drainage system}

274 The main goal of this study focuses on the comparison between the design of building drainage systems, based on the IDF curves proposed in Matos and Silva (1986) and the design based on IDF curves estimated for different periods of future scenarios for the

277 three rainfall regions (A, B and C, in Fig. 1). For quantitative comparison purpose and 
sake of simplicity, specific residential roof drainage gutter and rainwater pipe were considered as examples of building storm-water drainage systems to be designed. The flows were calculated with the rational method equation,

$$
Q=C . I . A
$$

where, the contribution area $(A)$ of the gutter is $100.14 \mathrm{~m}^{2}$, whereas the area of the devices that reach the rainwater pipe is $155.69 \mathrm{~m}^{2}$, the flow coefficient $(C)$ used for building coverings is equal to the unit while the precipitation intensity (I) was calculated according to the Equation (1) for a duration $(t)$ of 5 minutes and a return period $(T)$ of 10 years. Parameters $a$ and $b$ used in the calculation of the precipitation intensity follow the IDF curves established in the Regulation-decree n. ${ }^{\circ}$ 23/95 (DR 1995), and those obtained for precipitation data simulated for future scenarios A1B and B1, after correction of the climate model bias.

The gutter defined for conducting the storm water has a rectangular shape, with a base (B) of $20 \mathrm{~cm}$ and inclination $(i)$ of $0.5 \%$. It was dimensioned so that the height of the water depth $(h)$ therein does not exceed $7 / 10$ of the total height of the gutter. The Manning-Strickler's formula, Equation (10), was used with a roughness coefficient $(K)$ of $90 \mathrm{~m}^{1 / 3} / \mathrm{s}$, corresponding to metal plate. The hydraulic radius $(R)$ and the area occupied by the fluid $\left(A_{f}\right)$, in the case of rectangular sections, are determined by the Equation (11) and Equation (12), respectively:

$$
\begin{gathered}
Q=K \times A_{f} \times R^{2 / 3} \times i^{1 / 2} \\
R=\frac{B \times h}{(B+2 h)} \\
A_{f}=B \times h
\end{gathered}
$$


299 The residential rainwater pipe was designed using the Manning-Strickler formula (10)

300 for full section, roughness (K) of $120 \mathrm{~m}^{1 / 3} / \mathrm{s}$ corresponding to polyvinyl chloride (PVC)

301 and inclination $(i)$ of $2 \%$. The hydraulic radius $(R)$, in the case of a filled circular

302 section, is given by Equation (13), where $D_{i}$ is the internal diameter of the piping.

$$
R=\frac{D_{i}}{4}
$$

303

304

\section{Results and discussion}

305

306

307

308

309

310

311

312

313

314

315

Before focussing in the IDF curves in three precipitation regions, we analyse the precipitation distribution and projected changes for Continental Portugal. With this aim, the long term (1961 - 2000) average of the annual maximum daily precipitation depth was computed based on the ECAD precipitation dataset (Fig. 2). The obtained spatial pattern is dominated by a region of very large values $(>60 \mathrm{~mm})$, located over NW Portugal. This pattern is quite different from the three rainfall areas configuration proposed by Matos and Silva (1986) and adopted by the Portuguese legislator (Fig. 1).

Then, to assess potential future changes on extreme precipitation regime, four extreme precipitation indices were computed using the precipitation dataset simulated by COSMO-CLM for each of the 30-year periods for the C20, B1 and A1B scenarios, namely: the total precipitation depth (PRCTOT); the long-term 95th percentile (PRC95p); the ratio between RR95pTOT and PRCTOT (R95T); and, the total precipitation depth falling in days with daily precipitation amounts greater than the corresponding PRC95p (RR95pTOT). The computations were performed taking only into account wet days defined has days with precipitation depth above or equal to 1.0 $\mathrm{mm}$. 
321 Results obtained for simulated recent-past climate conditions (C20 scenario, 1971 322 2000) over continental Portugal (Fig. 1) reveals high spatial variability in the total 323 precipitation depth, with values ranging between $11 \times 10^{4} \mathrm{~mm}$ in the NW part of the 324 country and $1 \times 10^{4} \mathrm{~mm}$, in the remaining area of the country (Fig. 3(a)) resembling the 325 configuration of the average annual maximum daily precipitation depth (Fig. 2). This 326 spatial pattern is also very similar to the long term $95^{\text {th }}$ percentile of the daily precipitation depth (Fig. 3(b)), with highest values (as higher as $80 \mathrm{~mm}$ ) located over the NW quarter of country and in the southernmost region (of about $60 \mathrm{~mm}$ ) and much lower values (smaller than $45 \mathrm{~mm}$ ) elsewhere.

The spatial distribution of RR95pTOT and R95T also helps to understand the regime of extreme precipitation in Portugal. The spatial pattern of RR95pTOT (Fig. 3(c)) is very similar to the PRCTOT but, as expected, with much lower values. This means that precipitation amount falling in the days of extreme precipitation assume higher values in the same regions where total precipitation depth is greater. The $R 95 T$, which is a fraction (\%) of total precipitation depth falling during extreme rainfall days, present a pattern characterized by highest values (of about 30\%) in the southern part of the country and (of about 23\%) on NW part of the country and along the Tagus river basin (Fig. 3(d)).

Differences between the PRC95p ( $\triangle P R C 95 p$ ) obtained for each of the 30-year period of the future climate change SRES scenarios (B1 and A1B) and for the recent-past climate conditions (C20 scenario) are displayed in Fig. 4. For the B1 scenario, positive differences of 7 to $10 \mathrm{~mm}$ may be expected in the NW region with smaller magnitudes elsewhere for the 2011-2040 period (Fig. 4(a)). The pattern for the following period (2041 - 2070, Fig. 4(b)) is characterized by generally smaller values $(<5 \mathrm{~mm})$ while for the last 30-year period (2071 - 2100, Fig. 4(c)), resembles the 2011-2040 pattern except 
in the southernmost area, where a decrease (of about $-5 \mathrm{~mm}$ ) in PRC95p should be expected. This is a clear indication that natural variability on longer time scales may be superimposed on the long-term trends of precipitation associated with climate change. For the A1B scenario and 2011 - 2040 period (Fig. 4(d)), a modest increase of the PRC95p is revealed in all territory, except in small and sparse regions in NW part of the country. For latter periods (Fig. 4(e) and Fig. 4(f)), the pattern of the $\triangle P R C 95 p$ has the same but amplified spatial configuration with values as high as +10 to $15 \mathrm{~mm}$ in the NW region, over the Tagus river basin and southern part of the country for the 2071 2100 period.

Next, time series for the six weather stations are analysed. Given the ten temporal durations, three 30-year periods (2011 - 2040, 2041 - 2070, and 2071 - 2100) for each of the two future scenarios (A1B and B1) and one period for the recent past climate conditions, a total of 420 time series is considered. The visual inspection of the Quantile-Quantile plots and the value of the Kolmogorov-Smirnov statistical test (and corresponding $p$-value) confirm the goodness of fit of the Gumbel distribution function to all these time series. The probability density function for each scenario suggests that the return period for a given amount of precipitation intensity decreases for the three periods of the future scenarios vis-à-vis the period observed (not shown). Values of the IDF parameters $a$ and $b$ used here were obtained by linear regression, for durations times between 5 min and 30 min and return periods of 2, 5, 10, 20, 50 and 100 years. The quality of the regression was confirmed by the values of the coefficient of determination $\left(R^{2}\right)$, F-statistic and by the estimated error variance. The $R^{2}$ represents faction of the variance of the dependent variable (in this case, the precipitation intensity) by the linear model using the independent variable (in this case the duration). In all cases the values of $R^{2}$ were always higher than 0.99 , which means that more than $99 \%$ 
371 of the variance of intensity of precipitation can be explained by the variance of the 372 duration. The values of the F-statistic are used to assess the tests of nullity of 373 parameters for a given level of significance and it is reasonable to assume that the linear regression equation fits the data well because of the high value of the F-statistic and the $p$ - values tends to zero for a significance level of 5\%. Finally, the extremely small value of the estimated error variance obtained in all cases supports the idea that the regression line provides a good fit to the data.

The linear regression models based on the minimization of the squared error are based on a number of assumptions which are not always verified, e.g. the non-normality of the residuals, the existence of an asymmetric distribution of errors and outliers. This fosters the use of the RR method in this study, which constitutes an alternative approach that aims to be more robust and resistant than the OLS. Table 2 allows assessing changes in the design of a residential gutter and rainwater pipe, as a consequence of variations recorded in the IDF curves, as a result of the changes in the distribution of the maximum precipitation values due to climate change. The determination of the design flow was performed on the basis of the values of precipitation intensities estimated from the IDF curves for all time periods and both scenarios (after bias correction) and IDF curves currently used in designing building drainage systems in Portugal, developed by Matos and Silva (1986) and embraced by the Portuguese legislation (DR 1995).

Overall, there is a clear tendency to increase the size of gutters and rainwater pipes compared to the current dimensions defined in the Portuguese legislation (Table 2). However, changes are not uniform: For region A, the estimated increases in the height of the gutter for scenario A1B, range from 6\% (2041 - 2070) to 11\% (2071 - 2100) in the station of Ponte da Barca, to 30\% (2011 - 2040) to 39\% (2071-2100) in São Manços. For region B, the estimated increase may vary from 11\% (2041 - 2070) to 39\% 
(2071 - 2100) for Castelo Melhor and scenario A1B and from 12\% (2041 - 2070) to 28\% (2071 - 2100) for scenario B1. In the station of Pinelo, the design of the gutter varies from $-7 \%(2011-2040)$ and $18 \%(2071-2100)$ for scenario A1B, whereas, for scenario B1, it varies from 3\% (2011 - 2040 and 2041 - 2070) and 10\% (2071 - 2100). In order to obtain an average value representative for the mid-21st century, averages were built for each station over the three time periods, thus sampling decadal variability. This results for example on an estimated average increase of 39\% in São Manços and 9\% for Ponte da Barca for the A1B scenario (both Region A). For region B, changes are larger for Castelo Melhor (20\%) than for Pinelo (5\%) for both scenarios. On the contrary, little differences are found for region C: ranges are $3 \%$ to $16 \%$ for scenario A1B and from 3\% to $9 \%$ for scenario B1 in the station of Covilhã, whereas for the station of Pega, it ranges from $4 \%$ to $16 \%$ and from $3 \%$ to $6 \%$, respectively. Furthermore, averages were built over both stations in each region and both scenarios to obtain values representative per region considering scenario uncertainty. Averaged increase in Gutter dimension is likely to be higher in Region A (21\%) than in region B (12\%) and in region C (7\%).

The projected changes in the rainwater pipe size are essentially proportional to the gutter (Table 2). Therefore, a detailed presentation of the results is omitted. The main results are: (i) averaged changes in the rainwater pipe diameter increases from $4 \%$ in region $\mathrm{C}$, to $7 \%$ in region $\mathrm{B}$ and $11 \%$ in region $\mathrm{A}$; (ii) different behaviour in region $\mathrm{A}$ is characterized by higher changes in the weather stations located in the southern (São 417 Manços) than in the northern part (Ponte da Barca) and, in region B, at lower (Castelo Melhor) than at higher altitude (Pinelo); (iii) higher homogeneity in the expected changes in mountainous region $\mathrm{C}$ and (iv) changes are typically smaller than for the gutter. 
421 In general terms, the estimated changes are projected to be largest at the end of the $21^{\text {st }}$ century and under the conditions of scenario A1B scenario. In region C, there is a clear increasing trend in the changes (increases) in the size of these building storm-water drainage systems when the results for the three consecutive 30-year periods are analysed, independently of the scenario considered. However, this behaviour is not always observed in other regions where may even be expected decreasing trends (as in São Manços, located in region A, for the conditions of scenario B1), probably associated with natural variability on longer time scales. The temporal evolution of patterns of the 95th percentile, allow the interpretation of the results obtained for the expected changes in the dimensions of the rainwater collecting organs. In the case of the A1B SRES scenario, the expected changes in the size of the gutter and rainwater pipe along the three 30-year periods are characterized by increasing long-term trends in the Pinelo, Pega and Covilhã stations; for São Manços and Castelo Melhor, changes of similar magnitude are found for 2011 - 2040 and 2041 - 2070, which are enhanced for 2071 - 2100; For Ponte da Barca, a relative decrease is detected in the latter period at least for the B1 scenario (Table 2). As mentioned above, part of these relative changes between periods may be associated with multi-decadal natural climate variability and not with a long-term climate trend. These projected changes are consistent with the trends in the changes of PRC95p as discussed for the A1B scenario (Fig. 3).

Finally, it is important to underline that projected changes in the size of the building storm-water drainage systems are statistical significant at the $99 \%$ level in all cases except in the 6 cases (17\%) identified by a dagger in Table 2 and for the station of Pega in the first 30-year period of the A1B scenario. It is important to underline that projected changes in all cases of rainfall region A are statistical significant (99\%) and that statistical significance is higher in the end of the XXI century. 


\section{Conclusions}

448 This study aimed at discussing the current status of the IDF curves adopted by the

449 Portuguese Law and investigate the possible influence of projected changes in extreme 450 precipitation in the current designing of building storm-water drainage systems. Patterns 451 of spatial distribution of annual maximum daily rainfall and extreme precipitation 452 indices, obtained from both observed and simulated data for recent past conditions, exhibit considerable variability and suggest the necessity to revise the results of Matos and Silva (1986) included in the legislation (DR 1995), which divide Continental Portugal in three homogeneous rainfall regions. This is the case even assuming the long-term stationarity of current precipitation regime.

The developed methodology to assess the impacts of projected climate change is well grounded in literature and ensures the robustness and statistical significance of the results. The comparison of the design carried out with the IDF curves outlined for future scenarios with the curves obtained by Portuguese law allowed estimating an average increase of the gutter section and the rainwater pipe that is higher for region $\mathrm{A}$ ( $21 \%$ and $11 \%$, respectively) than for region $B(13 \%$ and $7 \%)$ and region $C$ ( $7 \%$ and $4 \%)$. Regarding the uncertainty for the three regions, estimated as the range between the two stations, estimates were similar for region C, with maximum increases of $16 \%$ for the gutter and $9 \%$ for the rainwater pipe. For region $\mathrm{B}$, the estimates for gutter design varies between $18 \%$ and $39 \%$ and, for the rainwater pipe range between $10 \%$ and $21 \%$. For region A, estimates are larger for southern Portugal (São Manços) - of 40\% for the gutter and 20\% for the rainwater pipe - than for Northern Portugal (Ponte da Barca), with $20 \%$ and $11 \%$ for the gutter and rainwater pipe, respectively. In spite of these uncertainties, the sign of the trends are very consistent between regions and stations. 
471 These tendencies are in line with the projected long-term changes of the 95th percentile

472 (PRC95p) and other extreme precipitation indices for under future climate conditions

473 which exhibit similar spatial patterns to the annual maximum daily rainfall. These

474 results, together with the spatial distribution of rainfall and extreme precipitation indices

475 seem to reinforce the suggested need to evaluate the precipitation regime classification

476 performed in Matos and Silva (1986).

477 Most cases studies discussed above (cf. Tab. 2) identified statistically significant

478 differences between the dimensions of the building storm-water drainage systems estimated for recent and future climate conditions. This is also the case for the nearfuture period of 2011 - 2041 and for the entire rainfall region A, which covers by far the largest part of the mainland area.

In summary, the impact of projected climate change should be reflected in the overall increase in the design of drainage storm-water drainage systems based on IDF curves as defined in Portuguese law for all scenarios and future periods analysed. Projected changes are typically larger and increasingly statistical significant for the end of the $21^{\text {st }}$ century, and the magnitude of the changes is larger for the scenario A1B than for scenario B1. Current laws and regulations relating to the design and management of hydraulic works may become out of date in the short term, given the increase in the frequency and intensity of extreme precipitation events. Therefore, the design of new building storm-water drainage systems for Continental Portugal should be modified to larger dimensions to mitigate the projected changes in extreme precipitation

Acknowledgements

We thank the MPI for Meteorology (Germany), the WDCC/CERA database and the COSMO-CLM community for providing the COSMO-CLM data. This work was 
496 supported by European Union Funds (FEDER/COMPETE - Operational

497 Competitiveness Programme) and by Portuguese national funds (FCT - Portuguese

498 Foundation for Science and Technology) under the project FCOMP-01-0124-FEDER-

499 022692. We thank Sven Ulbrich (Univ. Cologne) for help with data handling, Sandra

500 Dias (UTAD), Fátima Ferreira (UTAD) and Cristina Costa (ISEGI) for discussions. We

501 acknowledge the E-OBS dataset from the EU-FP6 project ENSEMBLES

502 (http://ensembles-eu.metoffice.com) and the data providers in the ECA\&D project

503 (http://www.ecad.eu).

504

505 
507 Ahammed, F., Hewa, G. A. (2012). "Development of hydrological tools using extreme 508 rainfall events for Dhaka, Bangladesh.” Water International 37(1), 43-52. 509 DOI: $10.1080 / 02508060.2012 .645191$

510 Arganis-Juárez, M. L., Domínguez-Mora, R., Cisneros-Iturbe, H. L., Fuentes-Mariles, 511 G. E. (2008). “Génération d'échantillons synthétiques des volumes mensuels écoulés de 512 deux barrages utilisant la méthode de Svanidze modifiée.” Hydrolog. Sci. J. 53, 130513 141. DOI: 10.1623/hysj.53.1.130

514 Ariff, N. M., Jemain, A. A., Ibrahim, K., Zin, W. Z. W. (2012). “IDF relationships using 515 bivariate copula for storm events in Peninsular Malaysia.” Journal of Hydrology 470, 516 158-171. DOI: 10.1016/j.jhydrol.2012.08.045

517 Bara, M., Gaal, L., Kohnova, S., Szolgay, J., Hlavcova, K. (2010). “On the use of the 518 simple scaling of heavy rainfall in a regional estimation of idf curves in slovakia.” 519 Journal of Hydrology and Hydromechanics 58(1), 49-63. DOI: 10.2478/v10098-010$520 \quad 0006-0$

521 Beijo, L. A., Muniz, J. A., Neto, P. C. (2005). “Tempo de retorno das precipitações 522 máximas em Lavras (MG) pela distribuição de valores extremos do tipo I.” Ciência e 523 Agrotecnologia 29, 657-667. DOI: 10.1590/S1413-7054200500030002

524 Ben-Zvi, A. (2009). "Rainfall intensity-duration-frequency relationships derived from 525 large partial duration series.” Journal of Hydrology 367(1-2), 104-114. 526 DOI: 10.1016/j.jhydrol.2009.01.007 
527 Bougadis, J., Adamowski, K. (2006). "Scaling model of a rainfall intensity-duration-

528 frequency relationship.” Hydrological Processes 20(17), 3747-3757.

529 DOI: 10.1002/hyp.6386

530 Brandão, C., Rodrigues, R., Costa, J. P. (2001). “Análise de fenómenos extremos, 531 Precipitações intensas em Portugal Continental.”

$532<$ http://snirh.pt/snirh/download/relatorios/relatorio_prec_intensa.pdf> (Feb. 1, 2013).

533 Coles, S. (2001). “An Introduction to Statistical Modeling of Extreme Values.” 534 Springer, London, UK, 209 pp.

535 Costa, A. C., Santos, J. A., Pinto, J. G. (2012). "Climate change scenarios for 536 precipitation extremes in Portugal." Theor. Appl. Climatol. 108, 217-234. 537 DOI: 10.1007/s00704-011-0528-3

538 Dame, R. d. C. F., Teixeira, C. F. A., Terra, V. S. S. (2008). "Comparison of different 539 methodologies to estimate intensity-duration-frequency curves for pelotas - rs, brazil.” 540 Engenharia Agricola 28(2), 245-255. DOI: 10.1590/S0100-69162008000200005

541 Das, S., Millington, N., Simonovic, S. P. (2013). "Distribution choice for the 542 assessment of design rainfall for the city of London (Ontario, Canada) under climate 543 change.” Canadian Journal of Civil Engineering 40(2), 121-129. DOI: 10.1139/cjce$544 \quad 2011-0548$

545 Diodato, N., Bellocchi, G., Romano, N., Chirico, G. B. (2011). "How the 546 aggressiveness of rainfalls in the Mediterranean lands is enhanced by climate change.” 547 Climatic Change 108, 591-599. DOI: 10.1007/s10584-011-0216-4 

República, 194/95(I-B). <http://www.dre.pt> (Feb. 1, 2013).

550 Endreny, T. A., Imbeah, N. (2009). "Generating robust rainfall intensity-duration551 frequency estimates with short-record satellite data.” Journal of Hydrology 371(1-4), 182-191. DOI: 10.1016/j.jhydrol.2009.03.027

Fowler, H. J., Kilsby, C. G. (2003). “Implications of changes in seasonal and annual

554 extreme rainfall.” Geophysical Research Letters 30, 1720-1723. DOI: 555 10.1029/2003GL017327

556 Frich, P., Alexander, L. V., Della-Marta, P., Gleason, B., Haylock, M., Klein Tank, A. M. G., Peterson T. (2002). “Observed coherent changes in climatic extremes during the 558 second half of the twentieth century." Climate Research 19, 193-212. DOI:10.3354/cr019193

Garcia-Marin, A. P., Ayuso-Munoz, J. L., Jimenez-Hornero, F. J., Estevez, J. (2013). "Selecting the best IDF model by using the multifractal approach." Hydrological Processes 27(3), 433-443. DOI: 10.1002/hyp.9272

Haslinger, K., Anders, I., Hofstätter, M. (2012). “Regional Climate Modelling over complex terrain: an evaluation study of COSMO-CLM hindcast model runs for the Greater Alpine Region.” Climate Dynamics 40, 511-529. DOI: 10.1007/s00382-012$1452-7$ (2008). “A European daily high-resolution gridded dataset of surface temperature and

569 precipitation.” J. Geophys. Res (Atmospheres) 113, D20119. DOI: 
571 He, J., Valeo, C., Chu, A., Neumann, N. F. (2011). "Stormwater quantity and quality

572 response to climate change using artificial neural networks.” Hydrological Processes 573 25, 1298-1312. DOI: 10.1002/hyp.7904

574 Holland, P. W., Welsch, R. E. (1977). “Robust Regression Using Iteratively Reweighted 575 Least-Squares.” Communications in Statistics: Theory and Methods A6, 813-827. 576 DOI: 10.1080/03610927708827533

577 Huber, P. J. (1981). "Robust Statistics.” John Wiley \& Sons New York, Hoboken, NJ, 578 USA.

579 IPCC (2012). “Managing the Risks of Extreme Events and Disasters to Advance 580 Climate Change Adaptation.” A Special Report of Working Groups I and II of the 581 Intergovernmental Panel on Climate Change, Field, C. B., Barros, V., Stocker, T. F., 582 Qin, D., Dokken, D. J., Ebi, K. L., Mastrandrea, M. D., Mach, K. J., Plattner, G.-K., 583 Allen, S. K., Tignor, M., Midgley P. M., eds., Cambridge University Press, Cambridge, 584 UK, and New York, NY, USA, 582 pp.

585 Karl, T. R., Nicholls, N., Ghazi, A. (1999). "CLIVAR/GCOS/WMO workshop on 586 indices and indicators for climate extremes: workshop summary.” Climate Change 42, 587 3-7. DOI: 10.1007/978-94-015-9265-9_2

588 Kingumbi, A., Mailhot, A. (2010). “Intensity-Duration-Frequency (IDF) curves: 589 comparison of annual maximum and partial duration estimators.” Hydrological Sciences 590 Journal-Journal Des Sciences Hydrologiques $\quad$ 55(2), 162-176. $591 \quad$ DOI: 10.1080/02626660903545995 
592 Kotlarski, S., Bosshard, T., Lüthi, D., Pall, P., Schär, C. (2012). “Elevation gradients of 593 European climate change in the regional climate model COSMO-CLM.” Climatic 594 Change 112, 189-215. DOI: 10.1007/s10584-011-0195-5

595 Kuo, C.-C., Gan, T. Y., Chan, S. (2013). "Regional Intensity-Duration-Frequency 596 Curves Derived from Ensemble Empirical Mode Decomposition and Scaling Property.” 597 Journal of Hydrologic Engineering 18(1), 66-74. DOI: 10.1061/(ASCE)HE.1943$598 \quad 5584.0000612$

599 Llasat, M. C. (2001). “An objective classification of rainfall events on the basis of their 600 convective features: Application to rainfall intensity in the northeast of Spain." 601 International Journal of Climatology 21(11), 1385-1400. DOI: 10.1002/joc.692

602 Lumbroso, D. M., Boyce, S., Bast, H., Walmsley, N. (2011). “The challenges of 603 developing rainfall intensity-duration-frequency curves and national flood hazard maps 604 for the Caribbean.” Journal of Flood Risk Management 4(1), 42-52. 605 DOI: 10.1111/j.1753-318X.2010.01088.x

606 Mailhot, A., Duchesne, S., Caya, D., Talbot, G. (2007). “Assessment of future change in 607 intensity-duration-frequency (IDF) curves for southern Quebec using the Canadian 608 regional climate model (CRCM).” Journal of Hydrology 347(1-2), 197-210. DOI: $609 \quad$ 10.1016/j.jhydrol.2007.09.019

610 Maraun, D., Wetterhall, F., Ireson, A. M., Chandler, R. E., Kendon, E. J., Widmann, M., 611 Brienen, S., Rust, H. W., Sauter, T., Themeßl, M., Venema, V. K. C., Chun, K. P., 612 Goodess, C. M., Jones, R. G., Onof, C., Vrac, M., Thiele-Eich, I. (2010). “Precipitation 613 downscaling under climate change: recent developments to bridge the gap between 
614 dynamical models and the end user." Rev Geophys 48, RG3003.

616

617

618

619

620

621

622

623

624

625

626

627

628

629

630

631

632

633

634

635

Matos, R., Silva, M. (1986). "Estudos de precipitação com aplicação no projeto de sistemas de drenagem pluvial. Curvas Intensidade-Duração-Frequência da precipitação em Portugal.” ITH24 LNEC, Lisbon, Portugal

Meehl, G.A., Stocker, T. F., Collins, W. D., Friedlingstein, P., Gaye, A. T., Gregory, J. M., Kitoh, A., Knutti, R., Murphy, J. M., Noda, A., Raper, S. C. B., Watterson, I. G., Weaver, A. J., Zhao, Z.-C. (2007). “Global Climate Projections.” Climate Change 2007: The Physical Science Basis. Contribution of Working Group I to the Fourth Assessment Report of the Intergovernmental Panel on Climate Change, Solomon, S., Qin, D., Manning, M., Chen, Z., Marquis, M., Averyt, K. B., Tignor, M., Miller, H. L., eds., Cambridge University Press, Cambridge, United Kingdom and New York, NY, USA, 747-845

Mohymont, B., Demaree, G. R., Faka, D. N. (2004). “Establishment of IDF-curves for precipitation in the tropical area of Central Africa - comparison of techniques and results.” Natural Hazards and Earth System Sciences 4(3), 375-387.

Nakicenovic, N., Alcamo, J., Davis, G., de Vries, B., Fenhann, J., Gaffin, S., Gregory, K., Grubler, A., Jung, T. Y., Kram, T., La Rovere, E. L., Michaelis, L., Mori, S., Morita, T., Pepper, W., Pitcher, H. M., Price, L., Riahi, K., Roehrl, A., Rogner, H.-H., Sankovski, A., Schlesinger, M., Shukla, P., Smith, S. J., Swart, R., van Rooijen, S., Victor, N., Dadi, Z. (2000). “Special Report on Emissions Scenarios.” Cambridge University Press, Cambridge, UK, 612 pp. 
636 Nie, L., Lindholm, O., Lindholm, G., Syversen, E. (2009). “Impacts of climate change 637 on urban drainage systems - a case study in Fredrikstad, Norway.” Urban Water 638 Journal 6, 323-332. DOI: 10.1080/15730620802600924

639 Olsson, J., Gidhagen, L., Gamerith, V., Gruber, G., Hoppe, H., Kutschera, P. (2012). 640 "Downscaling of Short-Term Precipitation from Regional Climate Models for 641 Sustainable Urban Planning.” Sustainability 4(5), 866-887. DOI: 10.3390/su4050866

642 Peck, A., Prodanovic, P., Simonovic, S. P. (2012). "Rainfall Intensity Duration 643 Frequency Curves Under Climate Change: City of London, Ontario, Canada.” Canadian 644 Water Resources Journal 37(3), 177-189. DOI: 10.4296/cwrj2011-935

645 Pereira, M. G., Calado, T. J., DaCamara, C. C., Calheiros, T. (2013). "Effects of 646 regional climate change on rural fires in Portugal.” Climate Research 57(3), 187-200. 647 DOI: $10.3354 / \mathrm{cr} 01176$

648 Peterson, T. C. (2005). “Climate change indices.” WMO Bulletin 54, 83-86.

649 Pizarro, R., Valdes, R., Garcia-Chevesich, P., Vallejos, C., Sangueesa, C., Morales, C., 650 Balocchi, F., Abarza, A., Fuentes, R. (2012). "Latitudinal analysis of rainfall intensity 651 and mean annual precipitation in Chile.” Chilean Journal of Agricultural Research 652 72(2), 252-261.

653 Pui, A., Sharma, A., Mehrotra, R., Sivakumara, B., Jeremiaha, E. (2012). “A 654 Comparison of Alternatives for Daily to Sub-Daily Rainfall Disaggregation.” Journal of 655 Hydrology 470-471, 138-157. DOI: http://dx.doi.org/10.1016/j.jhydrol.2012.08.041

656 Rockel, B., Will, A., Hense, A. (2008). “The Regional Climate Model COSMO-CLM 657 (CCLM).” Meteorologische Zeitschrift 17, 347-348. DOI: 10.1127/0941-2948/2008/030 
658 Rosenberg, E. A., Keys, P. W., Booth, D. B., Hartley, D., Burkey, J., Steinemann, A. C., 659 Lettenmaier, D. P. (2010). "Precipitation extremes and the impacts of climate change on 660 stormwater infrastructure in Washington State.” Climatic Change 102, 319-349. 661 DOI: $10.1007 / \mathrm{s} 10584-010-9847-0$

662 Rosenzweig, C., Major, D. C., Demong, K., Stanton, C., Horton, R., Stults, M. (2007). 663 "Managing climate change risks in New York City's system: assessment and adaptation 664 planning.” Mitig Adapt Strat Glob Change 12, 1391-1409. DOI: 10.1007/s11027-006$665 \quad 9070-5$

666 Sharif, M., Burn, D. (2007). “Improved K -nearest neighbor weather generating model.” 667 Journal of Hydrologic Engineering 12, 42-51. DOI: 10.1061/(ASCE)1084668 0699(2007)12:1(42)

669 Street, J. O., Carroll, R. J., Ruppert, D. (1988). “A Note on Computing Robust 670 Regression Estimates via Iteratively Reweighted Least Squares.” The American 671 Statistician 42, 152-154. DOI: 10.1080/00031305.1988.10475548

672 Svanidze, G. G. (1964). "Principles of Estimating River-Flow Regulation by the Monte 673 Carlo Method.“ Metsniereba Press, Tbilisi, USSR

674 Svanidze, G. G. (1980). “Mathematical Modeling of Hydrologic Series.” Water 675 Resources Publications, Fort Collins, Colorado.

676 Taylor, L. L., Banwart, S. A., Valdes, P. J., Leake, J. R., Beerling, D. J. (2012). 677 "Evaluating the effects of terrestrial ecosystems, climate and carbon dioxide on 678 weathering over geological time: a global-scale process-based approach.” Phil. Trans. 679 R. Soc. B 367(1588), 565-582. DOI: 10.1098/rstb.2011.0251 
680 Vasiljevic, B., McBean, E., Gharabaghi, B. (2012). "Trends in rainfall intensity for 681 stormwater designs in Ontario.” Journal of Water and Climate Change 3(1), 1-10. DOI: $682 \quad 10.2166 /$ wcc.2012.125

683 Veneziano, D., Lepore, C., Langousis, A., Furcolo, P. (2007). "Marginal methods of 684 intensity-duration-frequency estimation in scaling and nonscaling rainfall." Water 685 Resources Research 43, W10418. DOI:10.1029/2007WR006040

686 Veneziano, D., Yoon, S. (2013). "Rainfall extremes, excesses, and intensity-duration687 frequency curves: A unified asymptotic framework and new nonasymptotic results 688 based on multifractal measures." Water Resources Research 49(7), 4320-4334. 689 DOI: 10.1002/wrcr.20352

690 Zhu, J. (2013). "Impact of Climate Change on Extreme Rainfall across the United 691 States.” Journal of Hydrologic Engineering 18(10), 1301-1309. DOI: 692 10.1061/(ASCE)HE.1943-5584.0000725

693 Zhu, J., Forsee, W., Schumer, R., Gautam, M. (2013). "Future projections and 694 uncertainty assessment of extreme rainfall intensity in the United States from an 695 ensemble of climate models." Climatic Change 118(2), 469-485. DOI: 10.1007/s10584$696 \quad 012-0639-6$

697 Zhu, J., Stone, M. C., Forsee, W. (2012). “Analysis of potential impacts of climate 698 change on intensity-duration-frequency (IDF) relationships for six regions in the United 699 States." Journal of Water and Climate Change 3(3), 185-196. DOI: $700 \quad 10.2166 /$ wcc. 2012.045 
Table 1 - Weather stations used in this study. Characterization includes the code, name, abbreviation, altitude $(\mathrm{H})$, geographical coordinates (latitude, longitude), cover period 707 (P) and percentage of hourly precipitation missing values (MV).

\begin{tabular}{|c|c|c|c|c|}
\hline Code & Name & Altitude $(\mathrm{m})$ & Latitude $\left({ }^{\circ} \mathrm{N}\right)$ & Longitude $\left({ }^{\circ} \mathrm{W}\right)$ \\
\hline 03G/02C & Ponte da Barca, PB & 39 & 41.80 & -8.42 \\
\hline 23K/01UG & São Manços, SM & 190 & 38.46 & -7.75 \\
\hline 07O/05UG & Castelo Melhor, CM & 286 & 41.01 & -7.06 \\
\hline 04R/02G & Pinelo, PI & 607 & 41.63 & -6.55 \\
\hline 12L/03G & Covilhã, CO & 719 & 40.28 & -7.51 \\
\hline 11O/01G & Pega, PE & 770 & 40.43 & -7.14 \\
\hline
\end{tabular}

708

\begin{tabular}{|c|c|c|c|c|c|c|}
\hline Code & Name & Alt $(\mathrm{m})$ & Lat $\left({ }^{\circ} \mathrm{N}\right)$ & Lon $\left({ }^{\circ} \mathrm{W}\right)$ & $\mathrm{P}$ & MV (\%) \\
\hline 03G/02C & Ponte da Barca, PB & 39 & 41.80 & -8.42 & $01 / 2003-09 / 2012$ & 4.9 \\
\hline 23K/01UG & São Manços, SM & 190 & 38.46 & -7.75 & $02 / 2001-03 / 2012$ & 1.1 \\
\hline 07O/05UG & Castelo Melhor, CM & 286 & 41.01 & -7.06 & $10 / 2001-12 / 2009$ & 0.0 \\
\hline 04R/02G & Pinelo, PI & 607 & 41.63 & -6.55 & $02 / 2003-01 / 2012$ & 3.8 \\
\hline 12L/03G & Covilhã, CO & 719 & 40.28 & -7.51 & $05 / 1998-05 / 2010$ & 11.8 \\
\hline 11O/01G & Pega, PE & 770 & 40.43 & -7.14 & $10 / 2001-03 / 2012$ & 8.6 \\
\hline
\end{tabular}


Table 2 - Projected changes in the dimension of the drainage systems. Height of the Gutter $(\mathrm{H})$ and diameter of the rainwater Pipe (D) designed for weather stations located in the three pre-defined rainfall regions, using the precipitation intensity estimated by Portuguese law (DR 1995) and with data simulated by COSMO-CLM, for three periods of thirty years of the two future scenarios (A1B and B1) as well as the relative differences between these dimensions $(\Delta \mathrm{H}$ and $\Delta \mathrm{D})$. Projected changes are statistical significant at $99 \%$ level except for the cases identified by superscript lowercase letter $\left({ }^{\mathrm{a}}\right)$. Arithmetic averages of $\Delta \mathrm{H}$ and $\Delta \mathrm{D}$ for each weather station $\left(\overline{\Delta \mathrm{H}}_{w}\right.$ and $\left.\overline{\Delta \mathrm{D}}_{w}\right)$ and region and scenario $\left(\overline{\Delta \mathrm{H}}_{s}\right.$ and $\left.\overline{\Delta \mathrm{D}}_{s}\right)$ are also shown. The former values are calculated over different periods to obtain an average value representative for the mid- $21^{\text {st }}$ century, thus sampling decadal variability. The latter are derived to obtain values representative for each region considering scenario uncertainty.

\begin{tabular}{|c|c|c|c|c|c|c|c|c|c|c|c|}
\hline \multirow{2}{*}{\multicolumn{2}{|c|}{ Station }} & \multirow{3}{*}{$\begin{array}{l}\text { Scenario } \\
\text { DR n }{ }^{\circ} 23 / 95\end{array}$} & \multirow{3}{*}{ Period } & \multicolumn{4}{|c|}{ Gutter } & \multicolumn{4}{|c|}{ Rainwater pipe } \\
\hline & & & & \multirow{2}{*}{\begin{tabular}{|c|}
$\begin{array}{c}\mathbf{H} \\
\text { (cm) }\end{array}$ \\
4.51
\end{tabular}} & \multirow[t]{2}{*}{$\begin{array}{c}\Delta H \\
(\%)\end{array}$} & \multirow[t]{2}{*}{$\begin{array}{l}{\overline{\Delta \mathbf{H}_{s}}}_{\text {(\%) }} \\
(\%)\end{array}$} & \multirow[t]{2}{*}{$\begin{array}{l}\overline{\Delta \mathbf{H}}_{w} \\
(\%)\end{array}$} & \multirow{2}{*}{$\begin{array}{c}\begin{array}{c}\text { D } \\
(\mathbf{c m})\end{array} \\
96.60\end{array}$} & \multirow[t]{2}{*}{$\begin{array}{l}\Delta D \\
(\%)\end{array}$} & \multirow[t]{2}{*}{$\begin{array}{l}\overline{\overline{\Delta D}_{s}} \\
(\%)\end{array}$} & \multirow[t]{2}{*}{$\begin{array}{l}{\overline{\Delta \bar{D}_{w}}}_{w} \\
(\%)\end{array}$} \\
\hline \multirow{10}{*}{$\begin{array}{l}\varangle \\
.0 \\
.00 \\
\propto \mathscr{0}\end{array}$} & \multirow{4}{*}{$\begin{array}{c}\text { Ponte da } \\
\text { Barca }\end{array}$} & & & & & & & & & & \\
\hline & & A1B & $\begin{array}{l}2011-2040 \\
2041-2070 \\
2071-2100 \\
\end{array}$ & $\begin{array}{l}4.92 \\
4.79 \\
5.01 \\
\end{array}$ & $\begin{array}{r}9 \% \\
6 \% \\
11 \% \\
\end{array}$ & $9 \%$ & \multirow{9}{*}{$21 \%$} & $\begin{array}{c}101.48 \\
99.94 \\
102.57 \\
\end{array}$ & $\begin{array}{l}5 \% \\
3 \% \\
6 \% \\
\end{array}$ & $5 \%$ & \\
\hline & & B1 & $\begin{array}{l}2011-2040 \\
2041-2070\end{array}$ & $\begin{array}{l}5.28 \\
5.39\end{array}$ & $\begin{array}{l}17 \% \\
20 \%\end{array}$ & $17 \%$ & & $\begin{array}{l}105.50 \\
106.81\end{array}$ & $\begin{array}{l}9 \% \\
11 \%\end{array}$ & $9 \%$ & \\
\hline & & & 2071-2100 & $\begin{array}{l}5.14 \\
4.51\end{array}$ & $14 \%$ & & & $\frac{103.90}{96.60}$ & $8 \%$ & & $11 \%$ \\
\hline & \multirow{6}{*}{$\begin{array}{c}\text { São } \\
\text { Manços }\end{array}$} & & $2011-2040$ & 5.84 & $30 \%$ & & & 111.67 & $16 \%$ & & \\
\hline & & A1B & $2041-2070$ & 5.91 & $31 \%$ & $33 \%$ & & 112.38 & $16 \%$ & $17 \%$ & \\
\hline & & & 2071-2100 & 6.26 & $39 \%$ & & & 116.00 & $20 \%$ & & \\
\hline & & & 2011-2040 & 6.17 & $37 \%$ & & & 115.06 & $19 \%$ & & \\
\hline & & B1 & 2041-2070 & 5.61 & $24 \%$ & $26 \%$ & & 109.13 & $13 \%$ & $14 \%$ & \\
\hline & & & 2071-2100 & 5.28 & $17 \%$ & & & 105.57 & $9 \%$ & & \\
\hline \multirow{14}{*}{$\begin{array}{l}\infty \\
.0 \\
\ddot{0} \\
\ddot{0}\end{array}$} & \multirow{7}{*}{$\begin{array}{l}\text { Castelo } \\
\text { Melhor }\end{array}$} & $\mathrm{DRn}^{\circ} 23 / 95$ & & 3.89 & & & & 88.80 & & & \\
\hline & & & 2011-2040 & 4.50 & $16 \%$ & & \multirow{13}{*}{$12 \%$} & 96.52 & $9 \%$ & & \\
\hline & & A1B & 2041-2070 & 4.33 & $11 \%$ & $22 \%$ & & 94.34 & $6 \%$ & $12 \%$ & \\
\hline & & & 2071-2100 & 5.41 & $39 \%$ & & & 107.04 & $21 \%$ & & \\
\hline & & & 2011-2040 & 4.47 & $15 \%$ & & & 96.18 & $8 \%$ & & \\
\hline & & B1 & $2041-2070$ & 4.36 & $12 \%$ & $18 \%$ & & 94.76 & $7 \%$ & $10 \%$ & \\
\hline & & & 2071-2100 & 4.99 & $28 \%$ & & & 102.31 & $15 \%$ & & \\
\hline & \multirow{7}{*}{ Pinelo } & $\mathrm{DRn}^{\circ} 23 / 95$ & & 3.89 & & & & 88.80 & & & $7 \%$ \\
\hline & & & $2011-2040$ & 3.63 & $-7 \%$ & & & 85.34 & $-4 \%$ & & \\
\hline & & A1B & $2041-2070^{a}$ & 3.91 & $1 \%$ & $4 \%$ & & 89.01 & $0 \%$ & $2 \%$ & \\
\hline & & & 2071-2100 & 4.57 & $18 \%$ & & & 97.38 & $10 \%$ & & \\
\hline & & & $2011-2040^{\mathrm{a}}$ & 4.01 & $3 \%$ & & & 90.38 & $2 \%$ & & \\
\hline & & B1 & $2041-2070^{\mathrm{a}}$ & 4.00 & $3 \%$ & $5 \%$ & & 90.26 & $2 \%$ & $3 \%$ & \\
\hline & & & 2071-2100 & 4.27 & $10 \%$ & & & 93.74 & $6 \%$ & & \\
\hline \multirow{14}{*}{$\begin{array}{l}u \\
.0 \\
.00 \\
\ddot{0}\end{array}$} & \multirow{7}{*}{ Covilhã } & $\mathrm{DRn}^{\circ} 23 / 95$ & & 5.09 & & & & 103.44 & & & \\
\hline & & & $2011-2040^{\mathrm{a}}$ & 5.25 & $3 \%$ & & & 105.22 & $2 \%$ & & \\
\hline & & A1B & 2041-2070 & 5.37 & $5 \%$ & $8 \%$ & & 106.58 & $3 \%$ & $4 \%$ & \\
\hline & & & 2071-2100 & 5.89 & $16 \%$ & & & 112.09 & $8 \%$ & & \\
\hline & & & $2011-2040$ & 5.38 & $6 \%$ & & & 106.68 & $3 \%$ & & \\
\hline & & B1 & 2041-2070 & 5.53 & $9 \%$ & $6 \%$ & & 108.32 & $5 \%$ & $3 \%$ & \\
\hline & & & $2071-2100^{a}$ & 5.24 & $3 \%$ & & & 105.03 & $2 \%$ & & \\
\hline & & $\mathrm{DRn}^{\circ} 23 / 95$ & & 5.09 & & & $7 \%$ & 103.44 & & & $4 \%$ \\
\hline & & & $2011-2040^{b}$ & 5.29 & $4 \%$ & & & 105.64 & $2 \%$ & & \\
\hline & & A1B & 2041-2070 & 5.45 & $7 \%$ & $9 \%$ & & 107.48 & $4 \%$ & $5 \%$ & \\
\hline & Pega & & 2071-2100 & 5.93 & $16 \%$ & & & 112.53 & $9 \%$ & & \\
\hline & & & $2011-2040^{\mathrm{a}}$ & 5.24 & $3 \%$ & & & 105.09 & $2 \%$ & & \\
\hline & & B1 & 2041-2070 & 5.39 & $6 \%$ & $5 \%$ & & 106.76 & $3 \%$ & $3 \%$ & \\
\hline & & & 2071-2100 & 5.38 & $6 \%$ & & & 106.63 & $3 \%$ & & \\
\hline
\end{tabular}

${ }^{a}$ change is not statistically significant ( $p$-values $>0.05$ ).

${ }^{\mathrm{b}}$ change is statistically significant at $95 \%$ level 


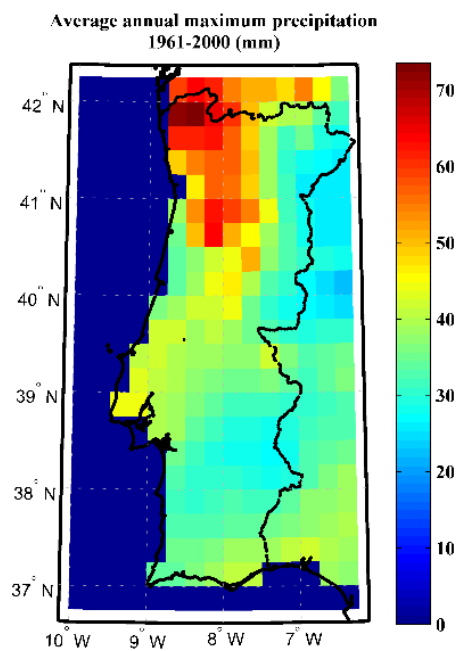
over Continental Portugal. 

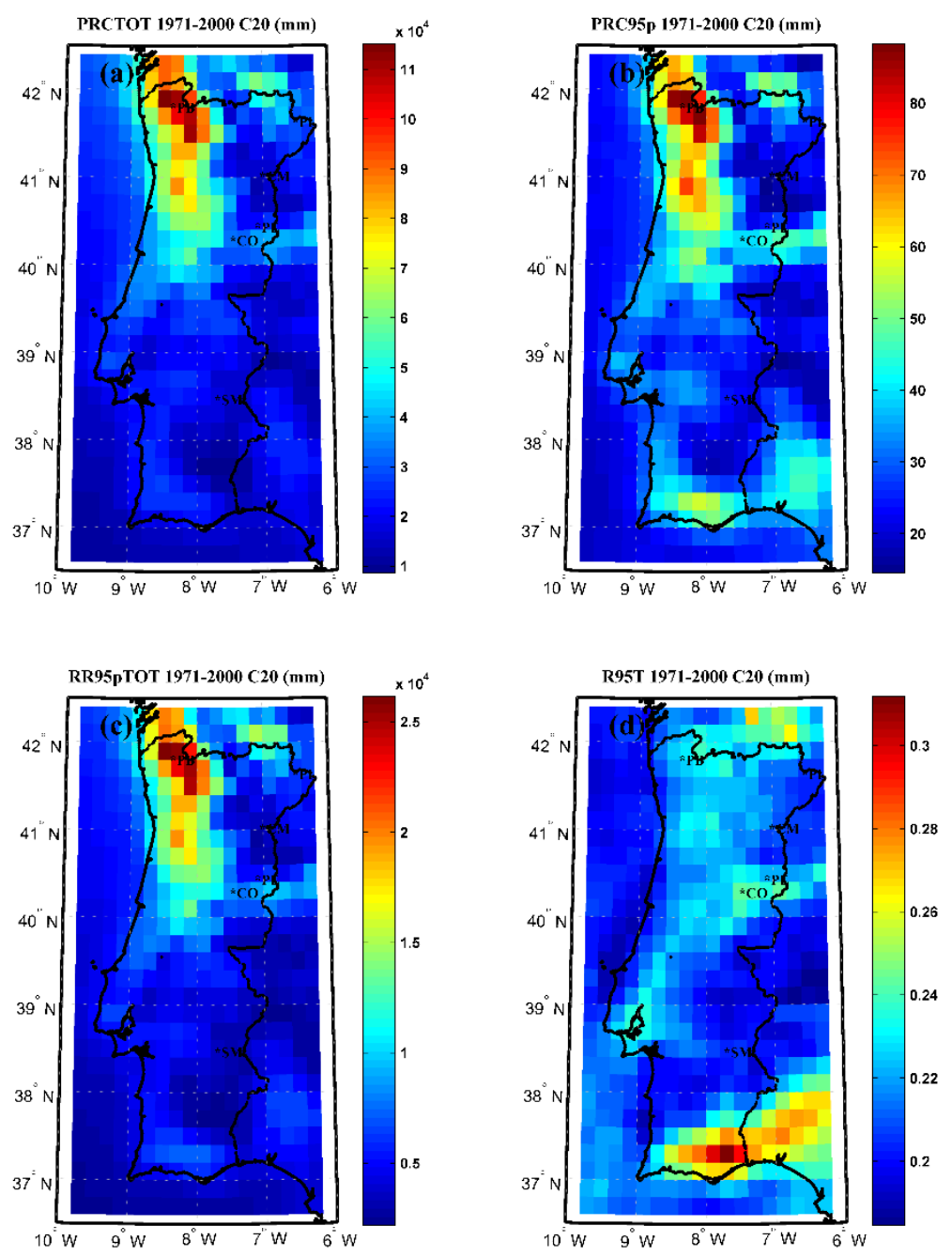

Figure 3 - Extreme Precipitation indices for Continental Portugal. Values of the (a) long-term 95th percentile (PRC95p), (b) total precipitation (PRCTOT), (c) total precipitation falling in days with daily precipitation amounts greater than the corresponding PRC95p (RR95PTOT) and (d) the ratio between RR95PTOT and PRCPTOT (R95T) evaluated for daily precipitation simulated by the COSMO-CLM model, for recent-past climate conditions (C20 scenario, 1971 - 2000). 

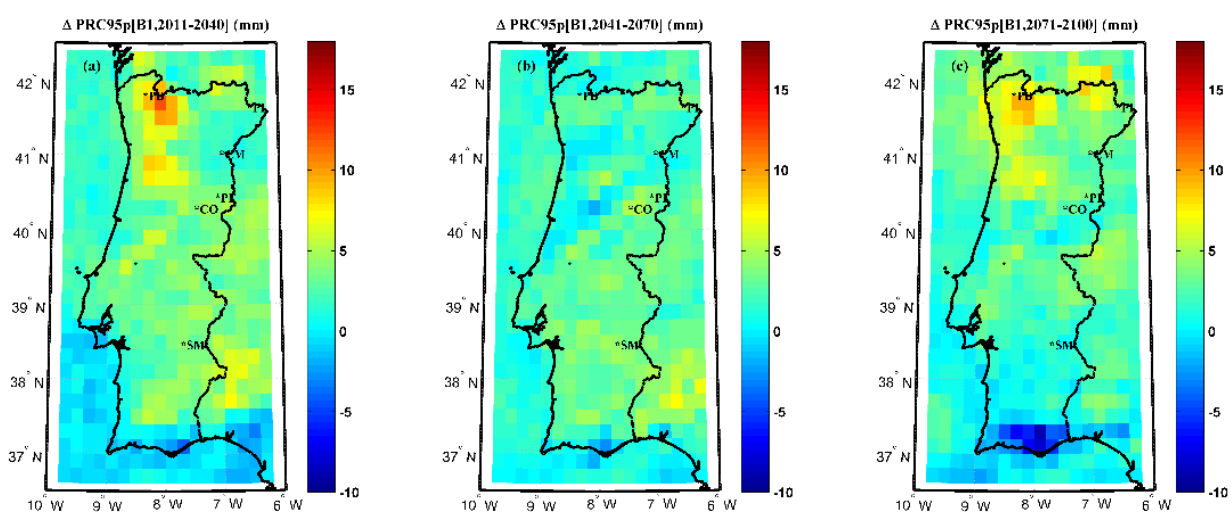

751
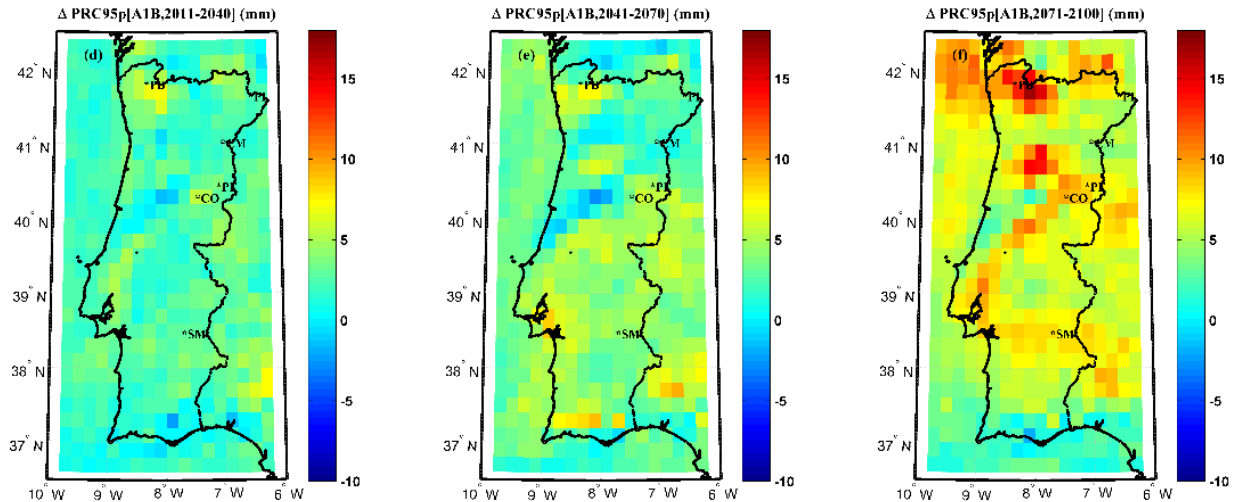

Figure 4 - Trends in long-term 95th percentile PRC95p over continental Portugal. Differences between of the long-term 95th percentile ( $\triangle P R C 95 p$ ) evaluated for future climate conditions under the B1 (top panel) and A1B (bottom panel) SRES scenarios and three 30-year periods 2011 - 2040 (left panels), 2041 2070 (middle panels) and 2071 - 2100 (right panels) in relation to recent-past climate conditions (C20 scenario, 1971 - 2000). 